\title{
Studies on Breeding and Feeding Practices in Karnal District of Haryana: A Descriptive Study
}

\author{
Surjya Kanta Roy* and B. S. Meena
}

Dairy Extension Division, ICAR-NDRI, India

*Corresponding author

\section{A B S T R A C T}

\section{Keywords}

Artificial insemination, Breeding practices, Feeding practices, Pregnancy diagnosis, Rectal palpation

\section{Article Info}

Accepted:

20 January 2020

Available Online:

10 February 2020
The study was all about assessing of breeding and Feeding practices followed of dairy farming by farmers in Karnal District of Haryana. Total eight villages of Karnal District were gleaned for this specific descriptive study.By random sampling all total 120 respondents were personally interviewed to know their followed dairy farming practices. The respondent farmers in all villages were well aware of different method of heat detection like bellowing, mucus discharge, frequent urination, mounting etc. All the respondents were practicing A.I and Pregnancy diagnosis at 60 days by either veterinary or paravet (as per the availability), for their animals like Indigenous cattle, Crossbreed cattle and Buffalo etc. Feed and fodder intake of animals were found as $18.32 \mathrm{~kg}, 6.05 \mathrm{~kg}$, $3.44 \mathrm{~kg}$ in green fodder, dry fodder and concentrate, respectively. For green fodder, they used to cultivate sorghum \& maize in summer and Berseem in winter for their animal. For dry fodder, they used to give paddy straw (parali), wheat straw, and rice husk, etc. in general. In different aspects of feeding practices among respondents were following two times feeding interval in feed, Fodder and water.

\section{Introduction}

As developing country like India where dairy farming always found to be a complimentary to the agricultural sectors, plays an important role to generate employments as well as regular income to the family with a sustainable growth. With consideration of socio-economic status of farmers regardless depends on interaction effect of both the sectors namely, agriculture as well as dairy farming. To availing of trio-benefits like resource mobilization, additional income and sustainability through dairy farming has a significant role to enhance not only farmers income but also in National income. Nonavailability of quality feed causes as an obstacle to reach animals' fullest potential in both productive and reproductive performance (Staal et al., 2008, NCA, 1976; Ranjhan, 
1994; NDRI, 1996). Balanced feeding mechanism has potential to increase animal performance with respect to enhance farmer income (Duncan et al., 2013; Patil and Udo, 1997). Inefficient management of data regarding different dairy farming practices makes policy makers clueless to formulate dairy animals-based scheme and other steps to bring significant remarks over there (Verma, 1989).

Another aspect like breeding practice also has contribution to obtain maximum yield through upgrading germplasm, pedigree selection etc. Different methods of heat detection were followed in all over the country in spite of bothering about the recommended practices. Both Breeding and feeding practices are important aspects of dairy farming to look for better performance and make it dynamic in competitive environment.

\section{Materials and Methods}

Karnal district of Haryana state was purposively selected for this descriptive study. The state Haryana positioned in the northern region of India. It is bordered by Punjab, Rajasthan, Delhi and Uttar Pradesh. Karnal district lies on western bank of river Yamuna. The river splits Haryana from Uttar Pradesh. Karnal district lies between $29^{\circ} 41^{\prime} 22.27^{\prime \prime} \mathrm{N}$ and $76^{\circ} 18^{\prime} 13.18^{\prime \prime}$ east longitude. Its height from sea level is approximately 257 metres. It is encircled by Kurukshetra district on its north and North West, Jind district on its south west and Panipat district on its south. The climate ranges from dry and hot summers to cold winters. Average annual rainfall is about 766 $\mathrm{mm}$. Net irrigated area is about $1,97,000$ hectares and forms 2,20,000 of the net cultivated area. Out of the 22 districts in Haryana State, Kamal district was selected purposively in this study.

Total eight village were selected randomly from two different block for present investigation purpose namely, Subri, Churni, Landora and Sanghoi from Karnal block Whereas from Indri Block, Gorgarh and Deepo, Norta and Dhamenheri. A list of farmers form each randomly selected villages was prepared who were having at least one milch dairy animal at the time of investigation and more than five years of experiences of dairy farming on the basis of pilot survey. The first hand information was gleaned by personal interview method from 15 respondents from each village, who were selected from the prepared list by applying simple random sampling technique. So, all total it consists 120 farmers were the main contributors of primary information to see the present scenario of Breeding and Feeding practices of dairy farming in Karnal district.

\section{Results and Discussion}

Breeding and feeding practices are the two pillar of animal husbandry management. By effective management of different animal husbandry management practices can harness maximum production by reach the genetical potentiality of animal. Delay in maturity, long dry period, poor conception rate etc. might be the result of inadequate breeding and feeding practices followed by the dairy farmers. It is impossible to get better yield from dairy animals without having the first-hand knowledge of effective management practices of dairy farm. Awareness of these practices not only for obtaining maximum output but also sustaining the scares resources.

\section{Existing breeding practices of dairy animals}

All the dairy farmers (Table 1) preferred A.I for upgradation and Pregnancy diagnosis at 60 days by either veterinary or paravet (as per the availability), for their animals like Indigenous cattle, Crossbreed cattle and Buffalo etc. with supporting of these findings, Satyarthi et al., (2003) revealed that 76.67 per cent of 
respondents were following A.I. for their animals. Another report, Sabapara et al., (2010) found that 96.50per cent of respondents used to practice A.I for breeding purpose of their animals. Rectal palpation was followed by all the respondents as a method of pregnancy diagnosis in the study area. Repeat breeding and anestrus were also found in study area whereas indigenous breed was found more repeat breeding as compared to crossbreed and buffalo.

In overall Karnal district the respondent farmers were well aware of different method of heat detection like bellowing, mucus discharge, frequent urination, mounting etc. About 11.67 per cent respondents were following late heat stage (after $18 \mathrm{hrs}$.) for insemination which was a cause of increased service period, with adding more than one uterus cycle. Whereas, 88.33 per cent respondents were following the standard recommendation that is mid heat stage (12-18 hrs.) for insemination.

The results of Patel et al., (2005), Chowdhry et al., (2006), Gupta et al., (2008), Rathore and Kachwaha (2009), Rathore et al., (2010), Sabapara et al., (2010), Menon (2009) and Hole (2016) are also referring the same phenomenon.

Menon (2009), stated that 95.83per cent of respondents recognized the onset of heat in animal by vaginal discharge and bellowing (29.16\%), 88.33per cent were inseminating within 12 hours of heat stage.

Rathore et al., (2010) found that 61.75per cent farmers inseminate at early stage of heat identification. They preferred para-vet mostly as an inseminator because of their availability at any time of requirement. With supporting of above-mentioned findings, the results of Sabapara et al., (2010), Gupta et al., (2008) and Singh et al., (2009b).
Feed and fodder offered to a lactating animal

Feed and fodder intake of animals were also calibrated by weighing method during the data collection researchers' himself recorded that how much quantity of feed and fodder were offered by farmers to their animals (Table2).For green fodder, they used to cultivate sorghum and maize in summer and Berseem in winter for their animal.

For dry fodder, they used to give paddy straw (parali), wheat straw, and rice husk, etc. in general. Overall in Karnal district farmers were feeding $18.32 \mathrm{~kg}$ in green fodder, 6.05 $\mathrm{kg}$ in dry fodder, $3.44 \mathrm{~kg}$ in concentrate, 28.91 gram in mineral mixture, and 14.45 gram in common salt in a daily basis. With supporting of this findings Mandal et al., (2004), Kumar et al., (2017), Kumar et al., (2006), Divekar (2016), Patel et al., (2005), Katariya (2007), Gupta et al., (2008) and Manohar et al., (2014).

The pattern of different composition of feed and fodder offering to their animals indicating dairy farmers potentiality to enhances their animal's productivity and maintained a balanced diet. Results also encouraged by Modi (2003), Chowdhryet al., (2006) and Sabaparaet al., (2015). Cultivation of green crops as a use of green fodder and dry fodder among respondents in study area supported by Rangammaet al., (2013), Rathore et al., (2010), Sabaparaet al., (2010), Aulakhet al., (2011), Akila and Senthilvel (2012) and Manohar et al., (2014).

\section{Existing feeding practices of dairy animals}

In different aspects of feeding practices in Karnal district were like most of the respondents were following two times feeding interval in feed, Fodder and water. Within two hours of parturition, they were feeding colostrum to the new-born calf (Table- 3). 
Table.1 Existing breeding practices

\begin{tabular}{|c|c|c|c|}
\hline \multicolumn{2}{|l|}{ Variables } & \multicolumn{2}{|c|}{$\begin{array}{c}\text { Respondents } \\
(\mathbf{n}=120)\end{array}$} \\
\hline & & \multirow{2}{*}{$\begin{array}{c}\mathrm{f} \\
120\end{array}$} & \multirow{2}{*}{$\begin{array}{c}\% \\
100.00\end{array}$} \\
\hline Breeding practice (A.I) & Indigenous Cattle & & \\
\hline & $\mathrm{CBC}$ & 120 & 100.00 \\
\hline & Buffalo & 120 & 100.00 \\
\hline \multirow{3}{*}{$\begin{array}{l}\text { PD (After } 60 \text { days of } \\
\text { conception) }\end{array}$} & Indigenous Cattle & 120 & 100.00 \\
\hline & $\mathrm{CBC}$ & 120 & 100.00 \\
\hline & Buffalo & 120 & 100.00 \\
\hline \multirow{3}{*}{$\begin{array}{l}\text { Method of PD (Rectal } \\
\text { Palpation) }\end{array}$} & Indigenous Cattle & 120 & 100.00 \\
\hline & $\mathrm{CBC}$ & 120 & 100.00 \\
\hline & Buffalo & 120 & 100.00 \\
\hline \multirow[t]{2}{*}{ No. Anestrus } & Indigenous Cattle & 1 & 0.92 \\
\hline & $\mathrm{CBC}$ & 7 & 1.20 \\
\hline \multirow[t]{3}{*}{ Repeat breeding incident } & Indigenous Cattle & 38 & 35.18 \\
\hline & $\mathrm{CBC}$ & 52 & 8.91 \\
\hline & Buffalo & 47 & 11.35 \\
\hline \multirow[t]{6}{*}{ Method of heat detection } & Bellowing & 120 & 100.00 \\
\hline & Mucus Discharge & 120 & 100.00 \\
\hline & Frequent Urination & 120 & 100.00 \\
\hline & Decreasing Rumination & 120 & 100.00 \\
\hline & Reduce feed intake & 120 & 100.00 \\
\hline & Mounting & 120 & 100.00 \\
\hline \multirow{2}{*}{$\begin{array}{l}\text { Allowed Stage of Heat for } \\
\text { Insemination }\end{array}$} & Mid Heat (12-18 hrs.) & 106 & 88.33 \\
\hline & Late Heat (after 18 hrs.) & 14 & 11.67 \\
\hline \multirow[t]{2}{*}{ Inseminators } & Para-vet & 120 & 100.00 \\
\hline & Veterinarian & 31 & 25.83 \\
\hline Method of PD & $\begin{array}{l}\text { By para-vet or Veterinary } \\
\text { Doctor }\end{array}$ & 120 & 100.00 \\
\hline Days of preference for PD & 60 Days & 120 & 100.00 \\
\hline
\end{tabular}


Table.2 Feed and fodder offered to a Lactating Animal

\begin{tabular}{|c|c|}
\hline Feed and fodder & Respondents(n=120) \\
\cline { 2 - 2 } & Av. Quantity of feed and fodder for one lactating animal/ day \\
\hline Green Fodder $(\mathbf{k g})$ & $18.32 \pm 4.84$ \\
\hline Dry Fodder $(\mathbf{k g})$ & $6.05 \pm 0.65$ \\
\hline Concentrate $(\mathbf{k g})$ & $3.44 \pm 1.02$ \\
\hline Mineral mixture $($ gram) & $28.91 \pm 22.26$ \\
\hline Common Salt (gram) & $14.45 \pm 11.13$ \\
\hline
\end{tabular}

Table.3 Existing Feeding Practices

\begin{tabular}{|c|c|c|c|}
\hline \multirow{2}{*}{\multicolumn{2}{|c|}{ Variables }} & \multicolumn{2}{|c|}{$\begin{array}{c}\text { Respondents } \\
(\mathbf{n}=120)\end{array}$} \\
\hline & & f & $\%$ \\
\hline \multicolumn{4}{|l|}{ Feeding Interval } \\
\hline \multirow[t]{2}{*}{ Fodder } & 2 Times & 111 & 92.50 \\
\hline & 3 Times & 9 & 7.50 \\
\hline feed & 2 Times & 120 & 100.00 \\
\hline \multirow[t]{2}{*}{ Water } & 2 Times & 111 & 92.50 \\
\hline & 3 Times & 9 & 7.50 \\
\hline Feeding of colostrum & Within two hours of birth & 120 & 100.00 \\
\hline \multirow[t]{2}{*}{ Quantity of colostrum feeding } & One quarter & 111 & 92.50 \\
\hline & Half quarter & 9 & 7.50 \\
\hline
\end{tabular}

A quarter of colostrum was feeding by most of the respondents to new-born calf. With favour of this findings Shinde et al., (2001), Satyarthi et al., (2003), Patel et al., (2005), Divekar and Saiyed (2008), Sabapara et al., (2010) and Sheikh et al., (2011).

Three- or two-times offering water depends of availability of water and season (in summer three times and in winter two times), practically they were well known about importance of water in feeding schedule. With supporting of this evidences Kochewad et al., (2013), Tanmay et al., (2002), Sabapara et al., (2010), Chowdhry et al., (2006) and Jadav et al., (2014).

In conclusion, different breeding and feeding practices have potential influence over the performance of dairy animals. With context of sustainability and profitable venture of dairy farming, the Karnal district has diverse germplasm with high potentiality in productive and reproductive performances, but that has to be maintained by following the scientific recommended animal husbandry management practices.

Practicing different latest breeding and feeding practices ensures their innovativeness as well as enthusiasm to remain in touch of scientific dairy farming. In Karnal district, farmers were well aware of different breeding and feeding practices and they were on it to enhance more productivity and high income.

\section{References}

Akila N, Senthilvel, K. Status of dairy farming in Karur district of Tamil Nadu. Indian J Anim. Res. 2012; 46(4):401-403. 
Aulakh GS, Yadav JS, Singh R. A study on adoption of recommended feeding practices by the buffalo owners of Punjab. Indian Journal of Animal Sciences. 2011; 81(6):631633.

Chowdhry NR, Patel JB, Bhakat M. An overview of feeding, breeding and housing practices of dairy animals under milk co- operative system in Banaskantha district of North Gujarat region. Dairy Planner. 2006; 5:8-10.

Divekar BS, Saiyed LH. Feeding practices followed by professional cattle owners of Anand district. Indian J. Field Vet. 2008; 3(4):31-34.

Divekar, B. (2016). Determinants of adoption of improved animal husbandry practises by the dairy farmers of kheda and panchmahal districts of middle gujarat (Doctoral dissertation, Ph. D. Thesis AAU, Anand (Gujarat)).

Duncan AJ, Teufel N, Mekonnen K, Singh VK, Bitew A, Gebremedhin B. Diary Intensification in developing countries: effects of market quality on farm-level feeding and breeding practices. Animal. 2013; 7:12: 2054-2062.

Gupta DC, Suresh A, Mann JS. Management practices and productivity status of cattle and buffaloes in Rajasthan. Indian Journal of Animal Sciences. 2008; 78(7):769-774.

Hole MR. Studies on Management Practices Followed by Cattle and Buffalo Owners in Latur Tahshil. M. Sc. (Agri) Thesis submitted to Vasantrao Naik Marathwada Krushi Vidyapeeth, Parbhani, 2016.

Jadav SJ, Rani DV, Pansuriya DV, Chaudhary JH, Chauhan VD, Pandya SS. Feeding Practices of Dairy Animals in Periurban Areas of Surat District(Gujarat). Int. J Advanced Multidisciplinary Res. 2014; 1(3):1-5.

Katariya MA. Assessment of feeding practices and status of certain minerals in dairy animals of Navsari district of South Gujarat. M. V. Sc. Thesis. Anand Agricultural University, Anand, 2007.

Kochewad SA, Singh VK, Singh MP. Dairy Cattle Management Practices Followed by Farmers of East Ganga Canal Command Area of upper Gangetic Plains of India. Indian J. Dairy Sci. 2013; 66(5):418-423.

Kumar, R., Singh, P. K., Goyal, R. K., Singh, H., and Kumhar, B. L. (2017). Existing Housing and Feeding Management Practices of Buffaloes in Firozabad District of Uttar Pradesh, India. International Journal of Current Microbiology AppliedScience, 6(5): pp. 1831-1838.

Kumar, U., Mehla, R.K., Chandra, R. and Roy, B. (2006). Studies on managemental practices followed by the traditional owners of Sahiwal cows in Punjab. Indian Journal Dairy Science, 59(2): pp. 100-105.

Mandal, A.B., Yadav, P.S. and Kapoor, V. (2004) Mineral status of buffaloes under farm feeding condition of Faridabad district of Haryana. Indian Journal of Animal Nutrition 21 (20): pp. 104-110.

Manohar DS, Goswami SC, Basant Bais. Study on Feeding Management Practices of Buffaloes in relationship with Selected Traits of Respondents in Jaipur District of Rajasthan, India, Indian J Anim. Res. 2014; 48(2):150154.

Menon, A.S., (2009). Differential adoption of scientific dairy farming practices and related Constraints. Indian Research Journal of Extension Education, 9(4): pp. 42-45.

Modi RJ, Patel NB. Breeding practices in dairy animals of rural area under milk shed of north Gujarat. Indian J Field Vet. 2010; 5(4):5-6.

Modi RJ. Study of dairy animal management practices in Sabarkantha district of North Gujarat. M. V. Sc. Thesis. Sardar krushinagar Dantiwada Agricultural University, Sardarkrushinagar, 2003.

National Commission on Agriculture. Part VII, Government of India, 1976.

NDRI. Estimates of nutrients requirement and availability for bovine population across major States in India, Publication, 1996, 281.

Patel JB, Patel NB, Prajapti KB, Brahmxatri KG. Animal husbandry practices for dairy animals in semi- arid region of Patan district. National seminar on 'Recent advances in conservation of Biodiversity and augmentation of reproduction and production in farm animals' held 5-7 March, 2005 at Sardar Krushinagar Dantiwada Agricultural University, Sardar Krushinagar, 2005, 253.

Patil BR, Udo HMJ. The Impact of Crossbred Cows in Mixed Farming Systems in Gujarat, India: Milk Production and Feeding Practices. 
Asian-Australasian Journal of Animal Sciences. 1997; 10(3):253-259.

Rangamma B, Jadeswararao S, Prasad RMV, Ragavarao E. Managemental practices adopted by buffalo milk producers in Krishna district of Andhra Pradesh. Indian J Anim. Prod. Mgmt. 2013; 29(1-2):61-68.

Ranjhan SK. Consultants reports on the availability and requirement of feed and fodder for Livestock and Poultry. Department of India, New Delhi, 1994.

Rathore RS, Kachwaha RN. Studies on existing management practices followed by the buffalo owners in Jhunjhunu district of Rajasthan. Indian Journal of Animal Production Mgmt. 2009; 25(1-2):8-11.

Rathore RS, Singh R, Kachwaha RN, Kumar R. Existing management practices followed by the cattle keepers in Churu district of Rajasthan. Indian Journal of Animal Sciences. 2010; 80(8):798-805.

Rathore, R. S., Singh, R., Kachwaha, R. N. and Kumar, R. (2010) Existing management practices followed by the cattle keepers in Churu district of Rajasthan. Indian Journal of Animal Sciences, 80(8): pp. 798-805.

Sabapara GP, Desai PM, Kharadi VB, Saiyed LH, Singh RR. Housing and feeding management practices of dairy animals in the tribal area of South Gujarat. Indian Journal of Animal Sciences. 2010; 80(10):1022-1027.

Sabapara GP, Fulsoundar AB, Kharadi VB. Milking and Health Care Management Practices Followed by Dairy Animal Owners in Rural Areas of Surat District, Sch. J Agric. Vet. Sci. 2015; 2(2A):112-117.

Sabapara GP, Fulsoundar AB, Kharadi VB. Profile of Dairy Farmers and Relationship with Adoption of Improved Dairy Husbandry Practices in Southern Gujarat, India,
Livestock Research International. 2016; 4 (1):36-40.

Sabapara, G. P., Desai, P. M., Kharadi, V. B., Saiyed, L. H. and Singh, R. R. (2010) Housing and feeding management practices of dairy animals in the tribal area of South Gujarat. Indian Journal of Animal Science, 80 (10): pp. 1022-27.

Satyarthi, P. N., (2003), George, T. (2004) and Murthi H., (2005). A comparative study of adoption of dairy farm technologies between non-members and members of dairy cooperative village. Indian Journal of AnimalSciences, 55(4): pp. 401-407.

Sheikh AS, Bhati DS, Sheikh W. Feeding practices followed by professional Kankrej cow owners of Banaskantha district of North Gujarat. Journal of Progressive Agriculture. 2011; 2(1):67-69.

Shinde, K. (2001). Prospects in adoption of animal husbandry practices in Haryana. Ph.D. Thesis, L.L.R. Veterinary University, Hisar, Haryana.

Singh, M., Chauhan, A., Chand, S., and Garg, M.K. (2009b) Identifying existing breeding and feeding practices as followed by the dairy owners in Rajasthan. Indian Journal of Animal Research 41(1):pp. 39-41.

Staal SJ, Pratt AN, Jabbar M. Dairy Development for the Resource Poor Part 3: Pakistan and India Dairy Development Case Studies. Rome: FAO, 2008, 44-3.

Tanmay S, Chander M, Mondal GP. Buffalo feeding practices of Vangujjars-A study in Tanda forest range of Uttranchal state. Indian J. Dairy Sci. 2002; 55(2):121-123.

Verma AK. Studies on buffalo housing and associated management practices in Haryana. Ph.D. Thesis, submitted to CCS Haryana Agricultural University, Hisar, 1989.

\section{How to cite this article:}

Surjya Kanta Roy and Meena, B. S. 2020. Studies on Breeding and Feeding Practices in Karnal District of Haryana: A Descriptive Study. Int.J.Curr.Microbiol.App.Sci. 9(02): 3026-3032. doi: https://doi.org/10.20546/ijcmas.2020.902.348 